\title{
Undocumented Narratives: Migrant Testimonio in La Migra me hizo los mandados
}

\section{Brittany Henry}

\author{
La migra a mí me agarró \\ 300 veces digamos \\ pero jamás me domó \\ A mí me hizo los mandados, \\ los golpes que a mí me dio, \\ se los cobré a sus paisanos \\ The border patrol has caught me, \\ say three hundred times, \\ but they haven't tamed me, \\ they can't get the best of me, \\ the beatings I took \\ were later paid for by their countrymen \\ Jorge Lerma ${ }^{1}$
}

In 2002, in the midst of a surge in nativist anti-immigrant politics, Los Angeles journalist Alicia Alarcón published La Migra me hizo los mandados, a collection of testimonios recounting the border-crossing experiences of twentynine California residents who immigrated to the United States from Mexico, Central America, and South America in the 1970s, 1980s, and 1990s. ${ }^{2}$ Alarcón's text, as well as its 2004 English translation, emerged in the wake of 9/11, as national security concerns heightened anti-immigrant sentiments and became 


\section{Brittany Henry}

rhetorical fodder for nativist activists concerned by the influx of Spanishspeaking immigrants. ${ }^{3}$ The book is one of several works published in the first decade of the new millennium intended to serve as a humanizing antidote to nativist rhetoric, including Rubén Martínez's Crossing Over: A Mexican Family on the Migrant Trail (2001) and Luis Alberto Urrea's The Devil's Highway: A True Story (2004). ${ }^{4}$ Alarcón's text is different from these journalistic accounts, however, for both the diversity of stories it contains as well as the way it foregrounds the voices of undocumented immigrants themselves. The stories contained in La Migra come from tales that were submitted by callers to Alarcón's radio talk show, which she read aloud on the air. Alarcón eventually collected the stories her callers submitted, performed an initial round of edits for clarity and readability, and after receiving permission from the narrators, submitted them to Arte Público Press to be compiled into a book. ${ }^{5}$ In both their radio and print form, these stories are representative of the increasing interest in migrant testimonio in recent years and signal the growing presence of testimonio in various mediums as part of the US political and literary landscape. ${ }^{6}$ Alarcón stages these testimonios as a form of political protest, employing the dual media of radio and print as technologies of resistance in response to the ever-increasing technologies of surveillance that have militarized the border and framed undocumented border-crossers as enemy combatants. While these testimonios speak collectively to migrants' persistent evasion of such surveillance technologies, they also underscore the high human costs of their efforts. ${ }^{7}$ In the process, I argue, the testimonios in La Migra offer a humanizing narrative that combats nativist panic, underscores the importance of lived experience to explanatory narratives of immigration, and models an intersubjective relationality that disrupts the nationalist mythology of the American Dream by uncovering the arbitrariness and ethical limitations of citizenship status as the prerequisite for inclusion in political community.

I begin by outlining how, in the context of nativist backlash against immigration in the late twentieth century, the dissemination of migrant testimonio via Alarcón's radio show and book creates a public space within which the undocumented community can speak back to anti-immigrant discourse. In the process, the testimonios Alarcón compiles function both as community building and as a mode of activism. Next, I argue that the stories the narrators recount humanize not only the "illegal" immigrant but also the history of immigration itself. As an alternative mode of historical narrative, the testimonios in La Migra decenter the role of the detached, anonymous observer as the voice of history and offer instead a form of embodied history that cannot be divorced from the individuals whose stories it tells. Following this analysis, I examine how representations of the visceral experience of migration in the testimonios emphasize the perilous and dehumanizing conditions of the journey north, while also bearing witness to the ways that bodies form intimate connections in extreme conditions to sustain one another. Here, I draw from Kelly Oliver's notion of "witnessing beyond recognition" to argue that the narrators perform a mode of witnessing as 
dialogic listening that models for the reader a form of relationality premised on affective connectivity and interdependency. ${ }^{8}$ My argument here recognizes an essential link between the breaking down of boundaries between self and other essential to the act of witnessing and the destabilization of national boundaries that undocumented crossing entails. I thus conclude by arguing that the arbitrariness of the border within the testimonios challenges nationalist paradigms and evinces the emergence of a distinctly transnational subjectivity, a subjectivity that, in conjunction with witnessing as a practice of listening, has transformative political potential.

\section{The Language of Resistance}

The last three decades of the twentieth century saw an influx of immigration from Mexico and Central America to the United States. This surge in south-north migration led to distinct demographic shifts in the United States, as the Latina/o population grew steadily. ${ }^{9}$ Despite the direct impact of US economic and military interventions on immigration trends in the late twentieth century, and despite the dependence of the US economy on immigrant labor, these demographic changes fueled racist, anti-immigrant sentiment among right-wing activists and politicians "who then pandered to the fears of the public." ${ }^{\prime 10}$ The specifics of this political response constitute the rhetorical backdrop for the increased danger of crossing to which the testimonios in La Migra bear witness and the political culture within which they were broadcast on the radio and circulated in print.

In her testimonio, which details the events surrounding her second journey across the US-Mexico border, Rosa María tells of her deportation after the Border Patrol raids the clothing factory where she works. She recalls that, though the raid was a big success for the Border Patrol, "[n]o llegaron las cámaras y la noticia salió escueta: 'Redada en fábrica de costura.' Nadie reportó de nuestro miedo, ni describieron la humillación de ser tratadas como delincuentes" (the television crews never came, and the newspaper article that was published was thin on details: 'Raid in a garment factory.' No one reported the fear that we felt, nor did they cover the humiliation of being treated like common criminals) (109). Rosa María's account underscores the dehumanizing nature of public representations of undocumented immigrants. While the news coverage of the raid demonstrated indifference to Rosa María and her fellow undocumented workers' existence and experiences, much nativist anti-immigrant discourse, especially during the 1990s and early 2000 s, was characterized by overtly demonizing rhetoric. Right-wing pundits and politicians pushed public debates on immigration far to the right and fostered nativist panic as they portrayed undocumented immigrants as criminals, as threats to national security and sovereignty, as a burden to the social welfare system, as polluters of American culture and values, as carriers of AIDS, and even (in the post 9/11 era) as potential terrorists. ${ }^{11}$ 


\section{Brittany Henry}

The public proved receptive to this rhetoric, in large part due to the emerging economic recession, ineffective local government, and feelings of socioeconomic insecurity, especially in California. ${ }^{12}$ Nativist activists, politicians, and scholars took advantage of both public anxieties about the economy and national and political concerns about the security of the border to "[declare] legislative political war against the migrant exodus." ${ }^{.13}$ Almost simultaneous with the implementation of NAFTA (the North American Free Trade Agreement) in 1994, the Clinton administration initiated Operation Gatekeeper, which sought to increase border security by militarizing the border. ${ }^{14}$ Operation Gatekeeper acted as a catalyst for anti-immigrant politics at the state level in California, as nativists proposed a series of xenophobic initiatives that sought to deny social services, healthcare, and public education to undocumented immigrants and their children; to dismantle affirmative action; and to eradicate bilingual education in the state. ${ }^{15}$

Such responses to the demographic shifts that resulted from the surge in immigration in the latter half of the twentieth century demonstrate the necessity of carving a space for migrant testimonio in debates about immigration and underscore the vital role of language as a mode of resistance. In 1986, largely as a result of anti-immigrant paranoia, English was made the official language of California. ${ }^{16}$ In the midst of a nativist "war on immigration" over the next several decades, language continued to be a battleground for anti-immigrant politics. The passage of Proposition 228 in 1998 effectively eradicated bilingual education in California. The growing prevalence of Spanish in the state became an irritant for racist sentiments, as to nativists the Spanish language became representative of the cultural threat posed by the Latina/o immigrant community. ${ }^{17}$ In this context, the broadcast of Alarcón's Spanish-language radio talk show, her invitation to members of the Latina/o community in California to publicly share their border-crossing stories on the air, and her eventual publication of these stories in Spanish all combat nativist legislation and activism.

The title of Alarcón's collection is drawn from the refrain of Jorge Lerma's corrido "Los Mandados," made popular in the 1980s by legendary ranchera singer Vicente Fernández. The song underscores the pervasiveness of undocumented immigration, the futility of the efforts by the Border Patrol to stop it, and the resilience and defiance of the singer who, undaunted by repeated deportations, ultimately achieves the objective of entering the United States..$^{18}$ According to Cathy Ragland, the song "emerged as an anthem for border-crossers (and relatives and friends in Mexico) ... [and] also served as a means for family members to support and share in the migrant experience." ${ }^{\prime 19}$ Alarcón's radio show and text, produced within a hostile political climate over four decades later, perform a similar community-building role. As Dolores Inés Casillas writes, "the 'experience of simultaneity' among a legion of listeners marks the precise moment when sentiments of community are echoed and realized through sound." ${ }^{20}$ The broadcast and publication of these testimonios contributed to the creation of community by enabling voices that were at best marginalized and 
at worst silenced in the nativist-dominated public debate about immigration to be transmitted and shared within the Latina/o community in California and beyond.

As the reference to the corrido in its title suggests, Alarcón's text highlights the importance and critical potential of oral storytelling traditions to marginalized communities, for whom alternative modes of production (folktales, corridos, broadcasts on local talk radio, oral histories) represent the voices of those who often lack access to dominant spaces of cultural production (whether it be the mainstream media or the institutionally recognized literary, artistic, and historical canon). For Alarcón and her callers, testimonio served as a critically productive form of oral history that challenged dominant narratives by giving voice to a community of undocumented border-crossers. For those who traverse legal parameters, who live beyond the bounds of the law because they lack socalled legal status, and who lack, therefore, designation as legitimate speaking subjects in the realm of national, public discourse, testimonio offers a way to speak back to the dominant culture. In Rosa María's case, for instance, while local news coverage disregarded her experience, Alarcón's radio show and book offered her the opportunity to narrate her own version of events and thus to craft a public counternarrative to the official account of the Border Patrol raid. Taken as a whole, La Migra demonstrates how a story told anonymously over the airwaves and transformed into a written text can create symbolic recognition for a community. To broadcast and publish a collection of border-crossing testimonios is to claim a public space for the undocumented immigrant community.

In the process of claiming this public space, Alarcón's invitation to her listeners to submit their stories to be read aloud on the air transforms oral communication from a zone of vulnerability (where speaking in one's native language may expose undocumented status, or an inability to adequately understand English speakers can result in legal, financial, and physical precarity) to a zone of expressive freedom, community, and hope. Commenting on the growth and political significance of Spanish-language radio in the context of anti-immigrant fervor, Casillas argues that sound, particularly on the radio, provides an ideal medium of communication among Latina/o immigrants, as it creates an alternative public space that is at once anonymous and intimate. ${ }^{21}$ In this sense, Alarcón's broadcasts offered a unique opportunity for undocumented immigrants, as individuals potentially isolated by linguistic hostility and legal precarity, to build community by sharing, listening, and responding to one another's stories in Spanish. In addition, the publication of the testimonios in print form in both Spanish and English entered the stories into a broader public sphere, thereby allowing the anonymous narrators to become participants in a broader network of advocacy by and on behalf of the US Latina/o community. Ultimately, by enabling undocumented immigrants to tell their own stories in multiple mediums, Alarcón's radio show and book intervened in a public discourse on immigration characterized by demonizing rhetoric. 


\section{Embodied History}

Beyond its intervention in a nativist-dominated political debate, as a form of oral collective biography, Alarcón's book also challenges official notions of what counts as history. Academically sanctioned accounts of the history of immigration often focus on facts offered by data and statistics derived from official reports and studies. While quantitative analysis of the structural conditions that propel immigration is useful and even necessary to combat misconceptions about migrants, structural analyses that stop short of representing the lived experience of the men and women who cross the border abstract the features of embodied history that testimonio offers. The limitations of responding to nativist discourse with detached structural analysis become particularly evident when we consider that current public debates look at undocumented immigrants as an abstracted, homogenous population and fail to account for the individual stories of the persons who risk everything to cross the border. It is the fundamental premise of both Alarcón's text and this essay, however, that migrant testimonio is an essential feature of any discussion of immigration because of the ways it foregrounds humanized historical memory. Arguing for the importance of testimonial writing, Marjorie Agosín states that because "memory is not always either arbitrary or objective ... the act of remembering represents a peculiar way of humanizing history." 22 Testimonio's disruption and reorientation of empiricist notions of objectivity makes the memory of lived experience important to the writing of human history. In this light, a published collection of testimonios such as La Migra me hizo los mandados participates in a project that humanizes not only the "illegal immigrant" but also history of immigration itself. Alarcón's book thus contributes to the writing of a different kind of history, one that looks to individuals who live in the midst of impersonal political and economic structures for knowledge and truth and that recognizes the importance and validity of personal stories as part of the cultural and historical archive.

Upon my first encounter with the text, I was struck by the lack of introductory material to help contextualize and historicize the testimonios for the reader and, I admit, was somewhat disconcerted by it. However, in light of Agosín's argument for the importance of memory and personal narrative in the writing of human history, I came to see the absence of introductory material in La Mig$r a$ as a strategic choice. The immediacy with which the testimonios confront the reader legitimizes the migrants as truth-tellers. By refusing to introduce an outside voice to contextualize the stories, the text relinquishes the supposedly objective voice of history and demands that we read the testimonios as history itself. Indeed, this demand to read personal narrative as history is implicit in the genre. As John Beverly writes,

[t]he word testimonio in Spanish carries the connotation of an act of truth telling in a religious or legal sense-dar testi- 


\begin{abstract}
monio means to testify, to bear truthful witness. Testimonio's ethical and epistemological authority derives from the fact that we are meant to presume that its narrator is someone who has lived in his or her person ... the events and experiences that he or she narrates. What gives form and meaning to those events, what makes them history, is the relation between the temporal sequence of those events and the sequence of the life of the narrator or narrators, articulated in the verbal structure of the testimonial text. ${ }^{23}$
\end{abstract}

In other words, as a true account of events the narrator experienced in time and in the body - rather than the autonomous observations of an anonymous interlocutor who may or may not have any real connection to the events presented - testimonio stands as history. Rather than assuming that real history is a narrative of facts compiled by an objective observer, La Migra gives priority to the stories that belong to and are told by the individuals who live through and are most impacted by the events they relate.

While no introduction is present to historicize the testimonios in La Migra, the historical, socioeconomic, and political forces that frame the stories of migration the text relates are woven into the testimonios themselves as the narrators recount their experiences. Martín begins the testimonio that opens the book by recounting that the day his father lost his job in 1979 "fue el día en que el president José López Portillo anunció el inicio de una era de prosperidad para México y todos los mexicanos" (was the same day that President José López Portillo proclaimed the beginning of a new era of prosperity for Mexico and all of its people) (1). When his father asks him if he believes the president's promises, Martín responds by repeating a refrain he has heard his mother voice many times: "Puras promesas y no hacen nada" (Promises, promises ... they never do anything) (1). Despite the president's assurances that Mexico's petroleum deposits will guarantee prosperity for all Mexican citizens, Martín's pessimism is justified in the months that follow as his father is unable to find employment and reports of government corruption and embezzlement by the director of Mexico's state-owned petroleum company PEMEX surface (2-4). Facing the prospect of starvation, Martín and his father make the difficult decision to leave the rest of the family behind and travel to the United States in search of work (3-4). Similar to Martín, Miguel Ángel recalls that he made the decision to leave Mexico in the 1970s because "al igual que a muchos millones de mexicanos, se me fueron las ganas de [creer al presidente] y con las ganas también se me fueron las esperanzas de que las cosas en México se pusieran major. La historia me comprobó que tomé la decisión correcta" (like millions of other Mexicans, I had lost any desire to believe in [the president], and I had lost all hope that things in Mexico were going to improve. History would show that I made the right decision) (164). 


\section{Brittany Henry}

While Martín and Miguel Ángel's testimonios speak to the economic crisis in the late 1970s and 1980s that impelled many Mexican citizens to migrate north ${ }^{24}$ Ulises's testimonio signals the exacerbation of economic precarity for Mexico's working class after the signing of NAFTA that resulted in a similar surge in immigration..$^{25}$ Overwhelmed by widespread conditions of poverty and unemployment, Ulises recalls that he made the decision to travel north with his sister in July of 1994, just six months after NAFTA was implemented (15). While other testimonios may lack specific historical markers that can locate them with certainty in a particular year or decade, they attest to the devastating effects on ordinary people of Mexico's economic structural adjustments and increasing dependence on foreign investment. While a handful of elites grew richer, economic ruin and desperation impelled countless individuals to migrate north from Mexico throughout the latter half of the twentieth century. ${ }^{26}$ Teresa, for example, notes that in addition to her inability to afford university tuition or to find employment, the desire to provide financial support to her grandfather, who was unable to get out of debt after losing his farm to the banks, played a significant role in her decision to move to the United States in search of work. Likewise, James recalls that he decided to leave his wife behind and migrate north because his job in Mexico did not pay enough to cover the cost of food, clothing, and transportation (158).

La Migra's many Central American narrators also bear witness to the conditions of extreme poverty and violence that caused millions to flee their homes in the last three decades of the twentieth century. ${ }^{27}$ Manuel, for instance, tells the story of his return to El Salvador for his father's funeral after his first journey north. As he relates his story, Manuel's memories of the natural beauty of his home country are tainted by his recollections of the country's extreme economic inequality and rampant violence. As he reflects on the contrast between the conditions of poverty facing the majority of El Salvador's population and the luxurious living of its oligarchic economic elite and the Anglo expatriates who are their business associates, he laments that "los ricos de El Salvador siempre tienen la vista atenta hacia arriba, disfrutan del paisaje de los volcanes" (the rich of El Salvador always have their sights set high, delighting in the volcano landscapes), while "los pobres ven hacia abajo, ven los craters de las montañas como heridas abiertas" (the poor keep their eyes to the ground, looking at the craters in the mountains like open wounds) (62). Manuel also recalls the increasing state violence that initially caused him to flee; he is haunted in particular by memories of a student massacre at the university he attended (60-61). As he tells the story of his return to El Salvador, Manuel explicitly situates his memories as a form of historical narrative. He states, "Regresaba como parte de la historia. Una historia de éxodo, de miedo, de represión por no pertenecer a un grupo determinado. Una historia de desertores y protagonistas. El Salvador se acribillaba a sí mismo. La guerra, la mugre, el desamparo. Los cuerpos asesinados de los compañeros de Universidad, la huida a Estados Unidos, todo despertaba en la memoria dormida" (I had returned as a part of history. A his- 
tory of exodus, of fear, of repression for not belonging to a particular group. A history filled with protagonists and deserters. El Salvador riddled itself with bullets. The war, the filth, the helplessness. The slain bodies of university classmates, the flight to the United States, all stirred in my sleeping recollections) (60). After arriving in El Salvador, Manuel finds that conditions have worsened rather than improved. To escape the violence that surrounds him, he embarks on the dangerous journey north once again, this time bringing his sister with him.

Another narrator named Manuel similarly recounts how, despite his love for his home country, he followed his grandmother's advice to leave El Salvador after seeing his neighborhood destroyed by war and many of his friends taken away by the army (103). José Luis states that he fled El Salvador after half of his family was killed in massacres in Sumpul and Mazoto to protect his own safety and because "para mí, quedarme en El Salvador era seguir sepultando a los muertos" (for me, staying in El Salvador meant continuing to bury the dead) (129). Pedro, who leaves Guatemala because his indigenous status makes him a target of violence, draws an equivalence between his own desperate situation and the situation he sees facing the Mexican migrants he meets as he travels through Mexico to reach the United States: "En Guatemala había Guerra, crueldad, intolerancia, en México había miseria, enfermedades y pocas esperanzas" (In Guatemala, there was war, cruelty, and intolerance, but in Mexico, there was poverty, sickness, and little hope) (137).

As these examples demonstrate, the testimonios in La Migra attest to the desperate economic and political situations that propelled migration in the latter half of the twentieth century. Throughout the text, the narrators recount this history on their own terms. Replacing the detached, anonymous observer (from whom we often expect to passively receive information), they offer instead a form of embodied history that cannot be divorced from the individuals whose stories it tells. The testimonios thus confront the reader with the lived experiences, emotions, and personhood of individuals whom official accounts of history depersonalize and homogenize and whom nativist politicians and pundits characterize as less than human. By telling personal stories that evoke an affective and personal response, La Migra initiates an interpersonal embodied history, a process of address and response that transforms history from an act of observation to one of witnessing.

\section{Corporeal Witnessing and Dialogic Listening}

This move toward witnessing as opposed to observation means that more than combating nativist discourse is at stake in La Migra's narration. Its embodied history holds the potential not only to change the terms of public debate by demanding recognition of the lived experience of undocumented immigrants but also to fundamentally transform modes of relationality between people, as it both performs and initiates a process of witnessing that goes, in Kelly Oliver's words, "beyond recognition." ${ }^{28}$ The concept of recognition, Oliver contends, is 


\section{Brittany Henry}

based on an unbreakable binary between sameness and difference, and thus it cannot move beyond conceiving of relations with others as essentially hostile. Oliver seeks to complicate the privileged role of recognition in models of subjectivity in order to challenge both "the Hegelian notion that subjectivity is the result of hostile conflict" as well as "notions of subjectivity based on a logic of exclusion." ${ }^{29}$ The pitfall of recognition, Oliver suggests, is that it "seems to depend on a particular notion of vision" as "an objectifying gaze" that upholds a hierarchy of dominance and subordination between the seer and the seen.$^{30} \mathrm{In}$ contrast to this visual scheme, Oliver posits a model of identity and subjectivity created through an affective connectivity that comes from mutually interdependent acts of address and response that she terms "witnessing." According to Oliver, witnessing occurs through the articulation and exchange of testimony and thus signifies in a double sense, "addressing and responding, testifying and listening." ${ }^{31}$ Oliver suggests that subjectivity is constituted through a process of acknowledging the ability of the self and the other in order to address and respond to one another. Rather than viewing the self as in fundamental opposition to others, this view of subjectivity recognizes the basic interdependency between people that sustains the lived experience of the self.

As opposed to the paradigm of sight that recognition implies, Oliver's notion of witnessing as a dialogic process of address and response suggests that subjectivity is rooted in discourse. However, despite the central role that dialogic listening seems to play in Oliver's concept of witnessing, ${ }^{32}$ she depends upon the paradigm of vision in the last part of her book when she articulates her work's intervention in theories of subjectivity. Oliver is largely interested in the potential of witnessing beyond recognition to counteract the psychic oppression of racism and the racial gaze. What is ultimately at stake in her concept of witnessing as a model of subjectivity is the reconfiguration of "the traditional notion of vision ... a the foundation of theories of recognition." ${ }^{33}$ Witnessing beyond recognition, Oliver concludes, entails a kind of affective revision of seeing as a "circulation of energy through connection and touch." 34

For Oliver, then, witnessing beyond recognition is ultimately about a new way of seeing others. However, drawing from the language Oliver herself uses to describe the process of witnessing - and taking into account the aural/textual as opposed to visual medium of testimonio - I want to suggest that witnessing that goes beyond recognition (rather than merely revising the concept) is also fundamentally about subjectivity as a practice of dialogic listening. To truly listen is to attend to the other in a way that decenters one's own perspective and thoughts in favor of the perspective and thoughts of another; attentive listening entails a radical openness to the address of the other. This openness resonates with Teresa Brennan's concept of "living attention." ${ }^{35}$ Brennan argues that affects are transmitted between persons and that the transmission of negative affects creates relational barriers between people that decrease their power to act. Embracing interdependency, however, can heal and reconfigure relations of hostility and can actually restore a sense of agency. Living attention is the 
mechanism for this transformation. "Attention to something other than oneself," Brennan writes, is "the living energy that enlivens" and can increase one's power to act (by, for example, transforming anger and fear into empathy and hope).$^{36}$ As a mode of living attention, dialogic listening has the potential to transform how we understand, address, and respond to one another. Given its ability to facilitate the kind of intersubjective encounter living attention entails, it is clearer to me how listening — as opposed to seeing — can facilitate the kind of transformative affective exchange Oliver locates at the heart of witnessing. Dialogic listening as the medium of address and response, additionally offers a more intuitive model for the kind of witnessing that occurs within and in response to La Migra, especially given its roots in community radio. Migrant testimonio, particularly in La Migra, involves acts of witnessing that go beyond recognition not because they reconstitute vision but rather because they are rooted in an altogether different locus of interaction and communication.

Emphasizing Oliver's description of witnessing as a dual process of both "addressing and responding, testifying and listening," I suggest that witnessing as a transformative mode of dialogic listening and living attention operates at multiple levels in relation to the testimonios found in La Migra. At the most immediate level, the narrators' acts of bearing witness through the articulation of embodied personal memory restore a sense of subjectivity and personhood fractured by the dehumanizing experience of perilous border crossings. As the narrators bear witness to the dangerous conditions of the journeys north to cross the US border, their stories provide a powerful account of how the experience of migration is registered in the body. This narration of the body, which is at the heart of the relational transformation that witnessing entails, offers a major intervention into public discourse on immigration. The immigration debate in the twentieth and early twenty-first centuries has focused increasingly on documentation and legality. In her discussion of Underground America, a collection of testimonios that focuses on the precarious situations faced by undocumented immigrants after their arrival in the United States, Marta Caminero-Santangelo argues that this practice has "in some ways, denied the embodiment of the 'illegal immigrant,' and to the degree that the body inevitably stands as metonym for the person, thus denied the immigrant's personhood as well. ${ }^{137}$ She further argues that the "insistence on the body in the testimony of the undocumented ... can be read as a counternarrative to the abstraction of personhood into the authority of documentation." ${ }^{38}$ Essentially, the emphasis on embodied experience in immigrant testimonio affirms the personhood of the speaking subject and combats the abstraction entailed in the focus on "legality" or "documentation." The firsthand descriptions of the visceral experience of migration in $L a$ Migra are thus part of the humanizing project of the text as a whole, as they bear witness to the physical danger, violence, and injustices faced by the narrators and the other migrants they encounter as well as to the strength and compassion that sustains them along the way. 
The bodily experience of the journey north is emphasized from the beginning of the book. In the opening testimonio, Martín recounts how he and his father crouched in tiny spaces on iron beams beneath a train car for days in order to arrive in the United States, forced to hold on for dear life to avoid being decapitated by the train's wheels. He recalls vividly how he struggled against muscle fatigue, heat stroke, hunger, and dehydration during the journey (5-10). After arriving in San Bernardino, Martín, along with his father and their companions, made the sixty-mile journey to Los Angeles on foot, exhausted from their experience on the train and fearful of being detained by immigration officials (10-13). In his testimonio, Martín remembers how he was hit by a car crossing the freeway and was forced to walk the remainder of the way to Los Angeles with a bruised head and hip and only one shoe (11). The physical precarity of the migrant body to which Martín testifies is reiterated throughout the other testimonios. Numerous narrators recount their struggles with hunger, dehydration, extreme temperatures, exhaustion, injury, and attacks by wild animals as they travel through remote areas by foot or cramped into tiny hidden compartments in automobiles in order to evade the Border Patrol. These stories testify to the dangers posed by the physical environment as well as to the injustices and violence migrants often face at the hands of those who seek to take advantage of their vulnerability. In addition to describing the dangers of crossing, many of the men and women recount their experiences of being extorted, beaten, assaulted, and robbed by soldiers, police, and coyotes, as well as their experiences being held in squalid conditions in so-called safe houses as they awaited instructions from their guides or for their family members to come and pay for their release. These descriptions testify to the lived experience of border crossing as it is registered in individual bodies. Through personal memory, the psychic wounding of the sensual, lived aspects of border crossing are counteracted. By recounting how these conditions were felt in the body, the narrators reassert and affirm the humanity that the experience threatened to rob from them.

Given the dialogic nature of witnessing, it is important to note that the healing power of these accounts lies not just in the act of articulation but also in the ability to speak these experiences to an attentive listener (in other words, in the process of address and response the narration of testimonio initiates). In their earliest iteration, the sharing of these stories publicly on Spanish talk radio facilitated dialogic listening as a process of community building. As Alarcón's audience listened to her read testimonios on the air and called in with comments, responses, and stories of their own, a process of witnessing as dialogic listening created a communal discursive space that transformed experiences of isolation and fear into relationships of connection and hope. In addition, the eventual publication of these stories in Spanish and in English enabled the testimonios not only to facilitate healing and forge community but also to function as an extrajuridical medium for addressing justice claims to an audience of 
readers who may offer an ethical response (and here the legal connotations of testimonio are especially fruitful).

In contrast to the lack of reporting and prosecution of crimes against migrants, the sharing of testimonios on the radio or in a book collection provides an alternative way for the abuses migrants experience to be publicly reported, remembered, and acknowledged. Alvarez and Zubieta note that while migrants routinely face crimes including robbery, extortion, beatings, and rape by police, coyotes, civilian citizens, and immigration agents, the majority decide not to make a formal complaint for fear of being detained because of their legal status, the futility of filing a report to police for police abuses, and the desire to avoid problems or delays in their travel. ${ }^{39}$ As the testimonios in La Migra reveal how the migrant body is vulnerable to the kinds of violence Alvarez and Zubieta mention, they bear particular witness to the gendered aspects of crossing through repeated descriptions of sexual assault. According to Olivia Ruiz Marrujo, it is estimated that between 80 and 90 percent of migrant women experience some form of gender-based violence. ${ }^{40}$ Among the twenty-nine testimonios in the text, I count at least ten instances of rape, attempted rape, threats of sexual violence, or abduction of female migrants. Ruiz Marrujo notes that despite its prevalence, sexual violence in particular is seldom reported and is "a poorly documented risk" to which "relatively little attention has been paid." While the publication of La Migra provides a general space for violence against migrant bodies to be documented and acknowledged, the transmission of the testimonios compiled in the book is especially significant given that several of the narratives testify to crimes that never had the chance of being reported officially given the death or abduction of persons (particularly women) traveling alone.

Henry, for instance, devotes a large part of his testimonio to recounting the experience of three Columbian sisters among the group he traveled with. Toward the end of his story, he recalls how they were all taken to a safe house after they crossed into the United States. At one point, everyone was told to go outside into the yard. Henry reentered the house to find a bathroom and walked into a room where he saw the three sisters being raped by the coyotes who served as the group's guides. He describes how the men assaulted him, but ultimately decided not to kill him since his friends still owed them money for crossing him (55-56). The next day, the women were nowhere to be found, and Henry was told that they had been taken back to Mexico to be crossed separately from the rest of the group. Henry describes the horror and disbelief he felt at what he witnessed, and the memory of these women haunts his testimonio. He describes how as the women's disappearance was explained to him, all he could think about was "la mirada suplicante de aquella jovencita que estaba siendo ultrajada de la forma más brutal, más inhumana" (the pleading look of that young woman, who was being violated in the most brutal, inhuman way) (57). As he waited for his friends to come and get him, Henry recalls that "no dejaba de pensar en las tres hermanas, las tres amigas, en la mirada suplicante de la 
más chica, la del lunar oscuro en el pómulo derecho" (I couldn't stop thinking about the three sisters, the three friends, about the pleading look of the youngest girl, the one with the dark mole on her right cheek) (58). By remembering these women as sisters and friends, Henry testifies to the bonds forged among strangers in transit. His narration refuses to let the coyotes' actions erase the women's lives and experiences and allows the reader to register his sense of shock and grief at the unspeakable violence he has witnessed.

In his testimonio, José Luis similarly focuses on the memory of a Nicaraguan woman who traveled alone. He recalls observing her deteriorating physical and emotional condition during the journey, and eventually watching in horror as she drowned in the current of a river the group was compelled to cross (130-32). He remembers the terror and grief he and his traveling companions experienced as a result of this woman's death and recalls that "esa noche lloré por la muchacha de Nicaragua" (that night I cried for the girl from Nicaragua) (132). José Luis also describes how once he reached the United States he was taken to a Motel 6 where he was held at gunpoint while the remaining women in the group were raped repeatedly by a group of coyotes. He recalls how during this experience he thought of the woman from Nicaragua and thought that perhaps it was better that the river had carried her away (133). José Luis's testimonio bears witness both to the tragic death of the woman from Nicaragua as well as the suffering of his other companions. He recounts how when they finally left the motel, "las muchachas parecían haber envejecido diez años. Caminaban lento, las piernas apretadas, la cabeza agachada. La mirada no era la misma. Volví a pensar en la muchacha de Nicaragua. Lloré gran parte del camino a Los Ángeles" (the girls appeared to have aged ten years. They walked slowly, legs together, heads down. Their faces were not the same. I thought again about the young woman from Nicaragua. I cried most of the way to Los Angeles) (133).

Caminero-Santangelo writes that "discourses of the body are part of a larger rhetoric of recognition based on an assumption of common humanity: [I]f you recognize the pain of my body, you are recognizing me as a fellow human being entitled to protection from the infliction of pain." 42 Though neither Henry nor José Luis were able to intervene in the situations they encountered, by bearing witness to these women's stories both men were able to perform an ethical act of remembrance that prevents these women's stories from being ignored and that recognizes the right of these (and all) women to be protected from such acts. As such, the inclusion of these women's stories in their own testimonios speaks to the particular types of injustice faced by the female migrant body and acts as a call from their listeners and readers for an ethical response rooted in solidarity, compassion, and retribution.

The narrators of these testimonios not only bear discursive witness to their own journeys and the journeys of others but also witness in their actions as they affectively sustain one another through, to borrow Oliver's language, "connection and touch." The narration of the body in these instances is more than a remembrance of violence and oppression; it is also a testament to the fundamental 
interconnectedness shared between human beings that is necessary for psychic and physical survival. Martín, for example, describes how his father yelled encouragements at him as they squatted for hours beneath a train car and told him stories to keep him from giving up (8-10). Fabiola describes how she witnessed a woman offer to breast-feed the baby of a stranger who was too emaciated to provide milk for her child (91). María recounts how she met a man from El Salvador during her second journey to the United States and offered to travel with him. As they struggled to make their way through remote terrain, María shared the little bit of candy she had with the man and refused to let him give up or to leave him behind (126-27). Miguel Ángel recalls traveling with a woman who had given birth days before the journey. Despite the fact that the coyote left her behind as she struggled to keep up with the group, Miguel Ángel stayed with her and rubbed tequila on her body several times throughout the night to keep her from dying (164-66). Pedro remembers how the coyote who acted as his guide covered him with trash and held him in his arms throughout the night to keep him from freezing to death (139). Antonio describes how his father refused to leave a heat-stroked man behind and stayed with him through the night as he recuperated (172). These accounts draw attention to the ways language and the body are intertwined and highlight the affective register of witnessing conceived as dialogic listening. In the process, the actions of solidarity narrated throughout La Migra powerfully acknowledge the "address-ability" and "response-ability" of others and affirm that our subjectivity is constituted not only through language but also through the body.

By recounting acts of witnessing as a corporeal mode of address and response, the testimonios in La Migra not only affirm the embodied nature of subjectivity but also perform a mode of relationality premised on reciprocity and care. The narrators' testimonios are stories not just of family members or friends banding together but also of strangers helping strangers. These accounts challenge notions of autonomous individuality. The testimonios express a sense of hope regarding the potential of a better life in the United States and an investment in the American Dream narrative (the idea that with individual hard work and perseverance anyone can attain prosperity). While attachment to this myth demonstrates a degree of investment in Western notions of individualism, the stories of interconnectedness with strangers during the journey north undermine this individualism and challenge the fundamental subject-object distinction upon which it is predicated. These moments model a practice of living attention that opens up the possibility of a radically different kind of community — one made up not of autonomous individuals pursuing their individual aims, but of interconnected persons acting for the good of others; one that is predicated not on a sense of national belonging or around notions of sameness, but rather on a process of witnessing that sees all human beings as deserving of help and respect regardless of their difference from one another.

As the narrators respond to the address of others by acting in solidarity and compassion, they model this practice of witnessing for their reader. As a result, 
the transformative potential of witnessing to which the testimonios in La Migra attest reaches beyond the text and into the social realm, as the stories perform and invite a process of active, dialogic listening that is potentially transformative both for speaker and listener. This account of the multiple levels of witnessing in La Migra demonstrates how conceiving of witnessing as a listening practice can potentially overcome one of the ambiguities in Oliver's theory. It is unclear in her work how precisely witnessing translates from a transformative action between individuals - between addresser and addressee - to transformative social action. The broadcast and publication of this kind of collective oral history exemplifies dialogic listening as a collective event and potential springboard to collective action. At this more collective level, testimonio forges community and intervenes in public discourse by facilitating transformative conversations, whether between callers on the radio or in discussions of the book in reading groups or classrooms.

\section{Border Crossing and Transnational Subjectivity}

At the same time that the linguistic and corporeal witnessing performed by the narrators of Alarcón's collection challenges boundaries between self and other, the narrators' accounts of illegal and illicit border crossings also threaten to disrupt political and geographic boundaries. Caminero-Santangelo argues that "for undocumented immigrants seeking legal status in the United States, overt suggestions of dual allegiances, to host and home countries, or (perhaps even more incendiary) of repeated crossings back and forth over borders, would be rhetorically dangerous, to say the least." ${ }^{23}$ As a result, she argues, one political strategy of human rights advocacy on behalf of undocumented immigrants has been to portray them as part of the national fabric - to argue that despite their illegal status, they are in fact "American," a strategy that demonstrates a sense of investment in the national project. ${ }^{44}$ La Migra demonstrates no such investment in expressing a sense of national belonging and focuses exclusively on the experience of border-crossing itself. For Caminero-Santangelo such a focus could potentially undermine "traditional highly bounded notions of national allegiances and identifications, ${ }^{35}$ which, I argue, makes the telling of these stories a potentially subversive act. Néstor Rodríguez writes that "Mexican immigrants see the US-Mexico boundary as a human, social artifact" rather than a "natural, self-evident divide." ${ }^{46}$ We see several instances of this view of the border in the testimonios. Fabiola, for instance, states that when confronted with the border wall, "me pareció curioso cómo una misma tierra podía estar tan celosamente dividida" (it seemed strange to me that the same land could be so jealously divided) (90). The arbitrariness of the border also strikes Salvador as he sits on the US side watching the ease with which US citizens are able to cross into Mexico. He states that "en ese momento pensé que no debería haber fronteras" (in this moment, I thought that there shouldn't be any borders) (180). In both cases, the confrontation with the border and the experience of crossing 
it leads the narrators to question the existence of the border or of any national boundaries at all.

The challenge to nationalism and to a sense of national belonging is also evidenced in the descriptions of multiple illegal crossings and the description of ties maintained to the country of origin. Ulises describes how after his initial move north, he continued to cross back and forth to see his family several times a year, "siempre burlando a la Migra" (always outsmarting/evading the Border Patrol) (30). Multiple narrators describe their continued financial and emotional attachments to family members they left behind. While the narrators of these testimonios maintain economic and emotional ties on both sides of the border, they do not demonstrate a sense of national belonging to nations on either side. The testimonios are characterized by a sense of pessimism, disillusionment, and disenchantment with the narrators' home countries due to the economic and political situations that impelled them to leave. Additionally, while the dream of a better life in the United States is a common thread connecting the narratives, and while visions of life in the United States are often romanticized, the attachment to the American Dream is not expressed as a desire to be "American" or to be included in the American national project. Antonio, for example, states that his excitement about obtaining citizenship is that it will enable him to cross back and forth between Mexico and the United States whenever he wants (174). As a child, Antonio lived in Mexicali and made money helping women who crossed the border to grocery shop by carrying their bags home. He notes that he would frequently cross to the US side of the border without creating any alarm (171-72). For Antonio, becoming a citizen is not about becoming American. Rather, citizenship reestablishes the fluidity of the border that he perceived as a child, before the wall was constructed, and before his attempts to cross back and forth were viewed with suspicion.

At the end of her testimonio, María describes how on her second journey north she avoided deportation when a Border Patrol agent boarded the train she rode to ask passengers for their papers. She responded to the agent's request by looking him in the eye and saying "American Citizen" (128). The power of these words to protect María from being detained and deported speaks to the potential citizenship holds for her. As in Antonio's case, being a citizen is not about achieving a sense of inclusion in a national project that validates the presence of national boundaries, but rather enabling the free and easy traversal of those boundaries. Additionally, María's ability to speak these words and convince the agent that she is a citizen (and thus has legal status), when in fact she is not, demonstrates the arbitrariness of the category itself. Just as illegally crossing the border calls into question the sovereignty of the nation, her ability to successfully portray herself as a citizen despite her illegal status destabilizes the very meaning of the term. In general, La Migra is not invested in portraying its narrators as participants in a national project. Instead, the narrators' descriptions of the border and of their experiences crossing it reveal the emergence of a distinctly transnational subjectivity. I term this subjectivity "transnational" to 
signal the ways it is rooted in a particular experience of space and place but not bound or determined by national belonging or identification.

This transnational subjectivity coalesces nicely with a model of subjectivity based on witnessing-as-listening; both are subjectivities that challenge artificial, socially constructed boundaries, be they between persons or nations. As the memories related by the narrators of Alarcón's collection testify to the transformative power of transgressive border crossings, their stories invite us, as readers, to witness in a way that challenges familiar notions of nationhood, autonomy, and bounded individuality and to engage in a practice of reading-aslistening that causes us to rethink the social and political spaces within which we, and those around us, live and move. At stake in this act of witnessing is the acknowledgment that the self and other are mutually constitutive and the reformulation of collective identity through dialogue - through speaking and, perhaps more importantly, listening to others. The link between witnessing and transnational subjectivity is crucial here, as the transnational subject positions of La Migra's narrators offer a way to imagine collectivity and relationality across the boundaries of geopolitics and race. Witnessing-as-listening not only breaks down the perceived boundaries between human bodies that result in hostile interpersonal relationality, witnessing in the context of transnational subjectivity can also break down the artificial and imagined boundaries of the national body that foster exclusive political relationality.

This new way of imagining collectivity is a crucial tactic in confronting one of the challenges of globalization - the return to nationalism. While globalization of the economy opens borders to "flows of capital, finance, manufactured goods, and services" and increases interdependency between nations, anti-immigration sentiment provides a way to hold onto notions of national sovereignty. ${ }^{47}$ In contrast to this reactionary return to nationalism, witnessing migrant testimonio enables the critical questioning of boundaries and the violence they enact and reframes our understanding of the historical, political, and economic conditions of migration in the late twentieth and early twenty-first century. As such, witnessing migrant testimonio can facilitate a different ethical standpoint from which to understand the questions of legality that frame immigration debates and that drive discourse on either side of the issue to arguments about citizenship and national belonging. Recent political events surrounding immigration-including nativist responses to the surge of Central American immigrant children seeking asylum in the United States in 2014, the unexpected success of Donald Trump's largely nativist-fueled 2016 presidential campaign, and President Trump's recently announced decision to rescind the Deferred Action for Childhood Arrivals (DACA) - underscore the dire need for this different standpoint. With legislation on immigration reform at the forefront of electoral politics today, debates about the best way to confront the crisis continue. Specific policy recommendations are beyond the scope and purpose of this essay. However, as a new form of politics conceived in direct opposition to the nationalist politics of exclusion and fear, witnessing-as-listening - and the 


\author{
affective transformation it entails - is an essential first step toward a just and \\ humane response to the crisis of immigration in the age of globalization.
}

\title{
Notes
}

I am grateful to participants in the 2013 Avanzamos: El Taller Chicana/o summer writing workshop at Rice University for their feedback on the earliest version of this project and to Gabriela Baeza Ventura at Arte Público Press for taking the time to sit down and talk with me about the conception and editorial process of Alarcón's book. I would also like to thank José F. Aranda and Rosemary Hennessy for their invaluable comments and suggestions throughout the writing and revision of the essay.

1. These lyrics form the chorus of the popular corrido, "Los Mandados," quoted in Cathy Ragland, Música Norteña: Mexican Americans Creating a Nation between Nations (Philadelphia: Temple University Press, 2009), 114.

2. Of the twenty-nine men and women whose voices are represented in the text, there are sixteen from Mexico, five from El Salvador, two from Guatemala, two from Honduras, one from Columbia, one from Perú, and one from Cuba. Alicia Alarcón, La Migra me hizo los mandados (Houston: Arte Público Press, 2001). Subsequent references to La Migra will appear parenthetically in text by page number. All translations are from the English edition of the book, published under the title The Border Patrol Ate My Dust (Houston, Arte Público Press, 2004). Page numbers, however, are exclusively from the original Spanish edition.

3. For more on the post-9/11 surge in nativist politics, see Joseph Nevins, Operation Gatekeeper: The Rise of the "Illegal Alien" and the Making of the U.S.-Mexico Boundary (New York: Routledge, 2002), 281-82.

4. Rubén Martínez, Crossing Over: A Mexican Family on the Migrant Trail (New York: Metropolitan Books, 2001); Luis Alberto Urrea, The Devil's Highway: A True Story (New York: Little, Brown, 2004).

5. The length and detail of the testimonios varies widely across the text. While some of the stories present well-developed narratives that include details of the authors' lives before and after the crossing, others consist of brief descriptions of the act of crossing alone. When possible, Alarcón followed up with the narrators to add detail to the stories and fleshed them out wherever possible. Ultimately, the editors at Arte Público decided to include the shorter narratives alongside the more developed ones rather than adding information or excluding them altogether. Editors standardized spellings and edited for grammar and sentence structure where necessary to make the text accessible to a general Spanish-speaking audience. There was, however, a concerted effort in the editorial process to maintain the integrity of the stories as penned by their original authors, which included leaving in regionalisms particularly representative of the narrators' communities of origin. Information on the book's publication process comes from Gabriela Baeza Ventura (Executive Editor, Arte Público Press), in discussion with the author, September 9, 2014.

6. In 2008, for example, the Voice of Witness book series published Underground America: Narratives of Undocumented Lives (San Francisco: McSweeny's Books, 2008), a collection of testimonios focusing on the lives and struggles of undocumented immigrants living in the United States. In a similar vein, the 2016 Democratic Primaries provide a compelling evidence of the growing presence of migrant testimonio in the realm of political discourse. Notable examples include the remarkable moment in the Univision Democratic debate between Hillary Clinton and Bernie Sanders on March 9, 2016, in which Guatemalan immigrant Lucía Quiej addressed the candidates in Spanish and preceded her question about immigration reform with the story of her husband's deportation; speeches at the Democratic National Convention on July 25, 2016, by 11-year-old Karla Ortiz, who spoke about her fears that her parents would be deported as her undocumented mother stood by her side; and Astrid Silva, whose speech consisted largely of a testimonio relating her experience crossing the border with her mother when she was 4 years old and her struggles growing up as an undocumented immigrant. See "Undocumented Woman Urges Candidates to 'Reunite the Families," Washington Post video, 3:56. March 9, 2016, https://www.washingtonpost.com/video/ politics/undocumented-woman-challenges-candidates-to-reunite-the-families/2016/03/09/55ae656 2-e657-11e5-a9ce-681055c7a05f_video.html; Janell Ross, "How Karla Ortiz, 11-Year-Old Daughter of Undocumented Immigrants, Made a Powerful Political Case," Washington Post, July 26, 2016, https://www.washingtonpost.com/news/the-fix/wp/2016/07/26/how-karla-ortiz-11-year-olddaughter-of-undocumented-immigrants-made-a-powerful-political-case/; and Gabby Morrongiello, "Illegal Immigrant Blasts Trump in DNC Convention speech," Washington Examiner, July 25, 2016, http://www.washingtonexaminer.com/illegal-immigrant-blasts-trump-in-dnc-conventionspeech/article/2597662.

7. Following the use of the term in the back matter of the book, I refer to the narratives in La Migra as "testimonios" throughout my essay. It is important to note, however, that the text lacks 


\section{Brittany Henry}

the overt political agenda that typically accompanies testimonio in the Latin American tradition. John Beverly, for instance, identifies the testimonios produced as part of the Central American revolutionary movements of the Cold War era as exemplars of the genre. See the introduction to Beverly, Testimonio: On the Politics of Truth (Minneapolis: University of Minnesota Press, 2004). In contrast to these examples, La Migra announces no political aim. Alarcón invited the narrators in the text to simply share their border-crossing stories, not to describe the injustices they faced during their migration experiences or to speak in order to convince others to act. While the testimonios in the text are not explicitly framed as stories of injustice, however, many of the stories speak to the unjust conditions that frame the migrant experience. Beverly writes that testimonio can act as a form of "resistance literature" either "implicitly or explicitly" (Ibid., 31). In order to qualify as testimonio, the "situation of narration ... has to involve an urgency to communicate, a problem of repression, poverty, subalternity, imprisonment, struggle for survival, implicated in the act of narration itself" (Ibid., 32). The narratives in La Migra, as my discussion of the text will make clear, fulfill this requirement. Apart from the various human rights violations to which the stories attest, the general dangers faced by those who undertake the undocumented journey across the border can be read as a form of injustice in light of an understanding of the structural conditions that leave many with no other viable option but to migrate. The narrators testify powerfully to these conditions and perform a model of witnessing that is potentially socially and politically transformative. As such, I maintain that the inclusion of La Migra in the genre's canon is justified.

8. Kelly Oliver, Witnessing: Beyond Recognition (Minneapolis: University of Minnesota Press, 2001).

9. In 1960, Latina/os comprised only 9 percent of the US foreign-born population. By 1970 , this number had increased by 19 percent, by 1980 it reached 33 percent, and by 1990 Latina/ os comprised 44 percent of the foreign-born population of the United States (Armando Navarro, The Immigration Crisis: Nativism, Armed Vigilantism, and the Rise of a Countervailing Movement (Lanham, MD: AltaMira Press, 2009), 99. Additionally, the Latina/o population grew from 4.5 percent of the overall population of the United States in 1970 to 12.5 percent in 2000. See United States Census Bureau, "Who's Hispanic in the U.S.?," 2010, https://www.census.gov/newsroom/ cspan/hispanic/2012.06.22 cspan hispanics.pdf.

10. Navarro, The Immigration Crisis, 99.

11. See Justin Akers Chacón and Julián Cordona, No One Is Illegal: Fighting Violence and State Repression on the U.S.-Mexico Border (Chicago: Haymarket Books, 2006), 237; Navarro, The Immigration Crisis, 102, 282.

12. Nevins, Operation Gatekeeper, 167.

13. Navarro, The Immigration Crisis, 118.

14. For a comprehensive overview of Operation Gatekeeper and its impact on undocumented immigration, see Nevins. Despite the belief held by Operation Gatekeeper's proponents that its efforts would deter migration, the project failed to address the socioeconomic conditions that had propelled migration for decades. As such, rather than impeding illegal border crossing, all that the project succeeded in doing was to push migrants to cross in more remote locations, thus increasing the physical dangers they faced (Navarro, The Immigration Crisis, 129).

15. These measures were introduced on the ballot as Proposition 187, Proposition 229, and Proposition 227, respectively. See Navarro, The Immigration Crisis, 135-38.

16. Ibid., 113.

17. See Thomas Muller, "Nativism in the Mid-1990s: Why Now?" in Immigrants Out! The New Nativism and the Anti-Immigrant Impulse in the United States, ed. Juan F. Perea (New York: New York University Press, 1997), 105-18, 106.

18. For the full text of the corrido with an English translation, see Celestino Fernández, "The Mexican Immigration Experience and the "Corrido Mexicano," Studies in Latin American Popular Culture 2 (1983): 115-30, 127-28.

19. Ragland, Música Norteña, 114. Ragland notes that the corrido, originally recorded in 1965, "remains relevant today." In addition to Vicente Fernández's popular rendition, it has been recorded by "numerous norteña and cumbia . . . artists through the years-including Monterrey's Los Bukis and Sinaloa's Bando el Recodo" (Ibid., 114).

20. Dolores Inés Casillas, ;Sounds of Belonging! U.S. Spanish-Language Radio and Public Advocacy (New York: New York University Press, 2014), 84.

21. Ibid.

22. Marjorie Agosín, ed., Inhabiting Memory: Essays on Memory and Human Rights in the Americas (San Antonio: Wings Press, 2011), xi.

23. Beverly, Testimonio, 3-4.

24. During the 1970 s and 1980 s, the Mexican government began to implement neoliberal free market reforms and initiated a new phase of industrialization backed by foreign investment. Rather than bringing economic self-sufficiency and prosperity to Mexico, however, these measures were accompanied by economic crisis, government corruption, and foreign (largely US) intervention in the Mexican economy. As a result, Mexican citizens experienced the intensification of poverty and unemployment, the decline of real wages, growing inequality, and social problems including 
increasing rates of crime and violence. Faced with increasingly poor socioeconomic conditions in Mexico, many felt they had no option but to migrate to the United States. See Chacón and Davis, 111-12; Patricia Zavella, "The Tables Are Turned: Immigration, Poverty, and Social Conflict in California Communities," in Immigrants Out! The New Nativism and the Anti-Immigrant Impulse in the United States, ed. Juan F. Perea (New York: New York University Press, 1997), 136-64, 139; Navarro, The Immigration Crisis, 124.

25. For a discussion of the adverse impact of NAFTA on Mexico's working class and its relationship to immigration, see David Bacon, The Children of NAFTA: Labor Wars on the U.S./Mexico Border (Berkeley: University of California Press, 2004); Navarro, Immigration Crisis, 125-6; John Cavanagh and Sarah Anderson, "Happily Ever NAFTA? A Bad Idea That Failed," Foreign Policy 132 (2002): 58-60; Paul Cooney, "The Mexican Crisis and the Maquiladora Boom: A Paradox of Development or the Logic of Neoliberalism?," Latin American Perspectives 28, no. 3 (2001): 55-83.

26. For a more detailed history of the impact of free trade reform on the Mexican people, see Bacon, Children of NAFTA, and Kelly Ojeda and Rosemary Hennessy, NAFTA from Below: Maquiladora Workers, Farmers, and Indigenous Communities Speak Out on the Impact of Free Trade in Mexico (San Antonio: Coalition for Justice in the Maquiladoras, 2006).

27. During the 1970s, 1980s, and 1990s in Central America-especially Nicaragua, Guatemala, and El Salvador - state violence (exacerbated by US military intervention), political repression, and widespread poverty and unemployment led millions to flee their homes and migrate north. See Alberto Alvarez and Ana Fernández Zubieta, "Human Rights Violations: Central American Immigrants at the Northeastern Mexico Border," in Human Rights Along the U.S.-Mexico Border: Gendered Violence and Insecurity, eds. Kathleen A. Staudt, Tony Payan, and Z. Anthony Kruszewski (Tucson: University of Arizona Press, 2009), 49-62, 50; María Cristina García, Seeking Refuge: Central American Migration to Mexico, the United States, and Canada (Berkeley: University of California Press, 2006), 14-33; and Navarro, Immigration Crisis, 98.

28. Oliver, Witnessing: Beyond Recognition, 9.

29. Ibid., 6.

30. Ibid., 11.

31. Ibid., 143.

32. I draw the concept of dialogic listening from Oliver's description of the process of witnessing. She writes, "Having a sense of oneself as a subject and an agent requires that the structure of witnessing as the possibility of address and response has been set up in dialogic relations with others (Ibid., 87-88). Subjectivity is thus "dialogic" rather than dialectic "because the subject is a response to an address from the other" (Ibid., 5).

33. Ibid., 143.

34. Ibid., 223. For her articulation of how witnessing challenges and reconstructs vision, see Oliver, Witnessing: Beyond Recognition, 171, 222.

35. Teresa Brennan, The Transmission of Affect (Ithaca: Cornell University Press, 2004), 40.

36. Ibid.

37. Marta Caminero-Santangelo, "Documenting the Undocumented: Life Narratives of Unauthorized Immigrants," Biography: An Interdisciplinary Quarterly 35, no. 3 (2012), 449-71, 464.

38. Ibid., 465.

39. Alvarez and Zubieta, 58.

40. Olivia Ruiz Marrujo, "Women, Migration, and Sexual Violence: Lessons from Mexico's Borders," in Human Rights Along the U.S.-Mexico Border: Gendered Violence and Insecurity, eds. Kathleen A. Staudt, Tony Payan, and Z. Anthony Kruszewski (Tucson: University of Arizona Press, 2009), 31-47, 31.

41. Ruiz Marrujo, "Women, Migration, and Sexual Violence," 32.

42. Caminero-Santangelo, "Documenting the Undocumented," 463.

43. Ibid., 460.

44. This strategy is employed, for instance, in Underground America.

45. Caminero-Santangelo, "Documenting the Undocumented," 460.

46. Néstor Rodríguez, "The Social Construction of the U.S.-Mexico Border," in Immigrants Out! The New Nativism and the Anti-Immigrant Impulse in the United States, ed. Juan F. Perea (New York: New York) 136-64, 238. 47. Nevins, Operation Gatekeeper, 172-73. 